\title{
HAK ATAS TANAH BAGI MASYARAKAT TRADISIONAL DI PANTAI: PERSPEKTIF HAK ASASI MANUSIA*
}

\author{
Muh. Afif Mahfud ${ }^{* *}$, Erlyn Indarti, dan Sukirno \\ Fakultas Hukum, Universitas Diponegoro \\ Jalan Imam Bardjo, S.H. No. 1, Pleburan, Semarang, Jawa Tengah, 50241
}

\begin{abstract}
Traditional People as minority deserve on land title. This research aims to describe protection of land title for traditional people in human right perspective and its principles. This research is doctrinal, use conceptual and statute approach Secondary data used is analysed qualitatively. The result shows there is no special declaration and convention regulating about land title for minoryt include traditional people and only broadening of housing right. There are several principles of traditional people protection, namely: non discrimination, Self-determination, progressive implementation and lastly and effective participation. Keywords: land title, traditional people, foreshore, human right
\end{abstract}

\section{Intisari}

Masyarakat tradisional sebagai minoritas yang bermukim di pantai berhak mendapatkan hak atas tanah. Penelitian ini mengkaji perlindungan hak atas tanah masyarakat tradisional dalam perspektif hak asasi manusia dan prinsip perlindungannya. Penelitian ini merupakan penelitian doktrinal menggunakan statute dan conceptual approach dengan data sekunder yang dianalisis secara kualitatif. Hasil penelitian menunjukkan belum terdapat konvensi maupun deklarasi khusus mengatur hak atas tanah bagi minoritas termasuk masyarakat tradisional sebagai perluasan hak atas perumahan. Prinsip perlindungan hak atas tanah masyarakat tradisional, yaitu: prinsip nondiskriminasi, Self-determination, implementasi progresif serta partisipasi efektif.

Kata Kunci: hak atas tanah, masyarakat tadisional, pantai, hak asasi manusia

\section{Pokok Muatan}

A. Latar Belakang Masalah 353

B. Metode Penelitian 355

C. Hasil Penelitian dan Pembahasan 356

1. Perlindungan Terhadap Hak Atas Tanah Bagi Masyarakat Tradisional dalam Perspektif Hak Asasi Manusia 356

2. Prinsip-Prinsip Perlindungan Terhadap Hak Atas Tanah Bagi Masyarakat Tradisional. 360

D. Kesimpulan 364

\footnotetext{
Hasil Penelitian didanai oleh Lembaga Pengelola Dana Pendidikan (LPDP) Tahun 2018
}

Alamat korespondensi: afifmahfud4@gmail.com. 


\section{A. Latar Belakang Masalah}

Dalam Pembukaan Undang-Undang Dasar Negara Republik Indonesia Tahun 1945 (UUD NRI 1945) diatur bahwa tujuan bangsa Indonesia adalah melindungi segenap bangsa Indonesia dan seluruh tumpah darah Indonesia serta untuk memajukan kesejahteraan umum. Kehendak untuk melindungi dan memajukan kesejahteraan tersebut kemudian dijabarkan dalam batang tubuh Undang-Undang Dasar NRI 1945 yakni pada Pasal 33 ayat (3) UUD NRI 1945. Dalam Pasal tersebut diatur bahwa bumi, air dan kekayaan alam yang terkandung di dalamnya dikuasai oleh negara dan dipergunakan untuk sebesar-besarnya kemakmuran rakyat.

Kemakmuran rakyat dalam Pasal 33 ayat (3) UUD NRI 1945 adalah kemakmuran rakyat Indonesia secara keseluruhan baik mayoritas maupun minoritas. Kesejahteraan rakyat akan tercipta apabila kepemilikan individual diakui dengan tetap berlandaskan hak menguasai negara. Kepemilikan pribadi merupakan hak asasi manusia sebagaimana diatur dalam Pasal $28 \mathrm{H}$ ayat (4) UUD NRI 1945 dan kepemilikan tersebut tidak boleh diambil secara sewenang-wenang oleh siapapun.

Kepemilikan pribadi termasuk kepemilikan tanah merupakan hak asasi bermakna masyarakat memiliki hak untuk mendapatkan perlindungan atas kepemilikannya sebagaimana diatur dalam Pasal 29 ayat (1) Undang-Undang No. 39 Tahun 1999 tentang Hak Asasi Manusia (UU HAM). Hal ini juga menimbulkan kewajiban bagi negara untuk melindungi kepemilikan atas tanah tersebut. Adanya perlindungan ini membuat orang bebas dan merasa aman untuk bermukim dan bergerak di tanah tersebut. Kebebasan untuk bergerak dan bermukim ini juga merupakan hak asasi manusia dalam Pasal 27 UU HAM.

Kewajiban negara bukan hanya terbatas untuk melindungi kepemilikan tanah tetapi memastikan bahwa tanah tersebut didistribusikan secara adil sehingga dapat dinikmati oleh semua masyarakat Indonesia. Dalam distribusi tersebut, perlu memperhatikan kondisi masyarakat yang kurang beruntung. Merujuk kepada Pasal $28 \mathrm{H}$ ayat (2) dan ayat (3) UUD NRI 1945, bagi masyarakat yang kurang beruntung dapat diberikan kemudahan dan perlakuan khusus dalam memperoleh hak atas tanah.

Kemudahan dan perlakuan khusus guna mendapatkan hak atas tanah berlaku bagi masyarakat yang kurang beruntung disebabkan masyarakat tersebut memiliki kemampuan yang terbatas dibandingkan masyarakat pada umumnya. Menyadari perbedaan kemampuan tersebut maka pemerintah harus membuat dan melaksanakan berbagai kebijakan untuk memastikan bahwa masyarakat yang kurang beruntung dapat memiliki hak atas tanah. Salah satu masyarakat yang kurang beruntung tersebut adalah masyarakat tradisional karena memiliki kemampuan yang lebih rendah baik dari sisi ekonomi dan pendidikan untuk mendapatkan hak atas tanah. ${ }^{1}$

Terminologi masyarakat tradisional dalam hukum nasional pertama kali muncul pada Undang-Undang No. 1 Tahun 2014 tentang Perubahan Undang-Undang No. 27 Tahun 2007 tentang Pengelolaan Wilayah Pesisir dan PulauPulau Kecil. Oleh sebab itu, definisi masyarakat tradisional dalam undang-undang ini dikaitkan dengan kegiatan penangkapan ikan. Dalam Pasal 1 angka 35 Undang-Undang No. 1 Tahun 2014 tentang Perubahan Atas Undang-Undang No. 27 Tahun 2007 tentang Pengelolaan Wilayah Pesisir dan Pulau-Pulau Kecil diatur bahwa masyarakat tradisional adalah masyarakat perikanan tradisional yang masih diakui hak tradisionalnya dalam melakukan kegiatan penangkapan ikan atau kegiatan lainnya yang sah di daerah tertentu yang berada dalam perairan kepulauan sesuai dengan kaidah hukum laut internasional.

Masyarakat tradisional ini harus dibedakan dengan masyarakat hukum adat sebab masyarakat

Sidi Rana Menggala, "Kemiskinan Pada Masyarakat Nelayan di Cilincing”, Indonesian Journal of Public Administration, Vol. 2, No. 1, Januari- Juni 2016. hlm. 62 
hukum adat menekankan kepada kemampuan dan kewenangan masyarakat tersebut untuk mengurus wilayahnya sendiri secara mandiri dan harus memenuhi aspek struktur hukum adat, pranata hukum adat, wilayah adat dan adanya masyarakat hukum adat. ${ }^{2}$ Hal ini berbeda dengan masyarakat tradisional yang menekankan pada cara hidup masyarakat yang masih tradisional baik dari sisi alat tangkap, tujuan penangkapan ikan dan dapat juga melakukan kegiatan lain termasuk bermukim di wilayah tersebut.

Pendirian permukiman bagi masyarakat tradisional dilakukan di pantai yaitu perairan pesisir yang diukur dari pasang tertinggi sampai surut terendah. Pendirian permukiman di pantai sudah terjadi sejak 1.000 tahun lalu. ${ }^{3}$ Indonesia sendiri, permukiman masyarakat tradisional Suku Bajo di pantai sudah ada sejak abad 15 Masehi. ${ }^{4}$ Pada tahun 2015, jumlah rumah masyarakat tradisional Suku Bajo di Kabupaten Buton Tengah, Provinsi Sulawesi Tenggara khususnya di Desa Tanailandu dan Desa Terapung mencapai 163 rumah. Adapun di salah satu desa di Kabupaten Muna Barat yakni Desa Tanailandu, rumah di pantai mencapai 185 unit. Kelurahan Bajoe, Kabupaten Bone, Provinsi Sulawesi Selatan terdapat 35 rumah masyarakat tradisional Suku Bajo yang terletak di pantai. ${ }^{5}$

Pendirian permukiman oleh masyarakat tradisional tersebut menggunakan tanah yang berada di pantai sebagai bagian dari laut. Dalam hukum agraria, tanah didefinisikan sebagai permukaan bumi baik yang berada di daratan maupun di bawah air termasuk air laut. ${ }^{6}$ Definisi tanah yang serupa juga dikemukakan oleh Bernhard Limbong bahwa tanah adalah permukaan bumi termasuk yang terletak di bawah perairan sepanjang dapat dilekati hak penggunaan dan penguasaan di atasnya. ${ }^{7}$

Guna mengatur hubungan hukum antara manusia dengan tanah ini maka negara berdasarkan hak menguasainya berwenang untuk mengatur hubungan-hubungan hukum dan perbuatanperbuatan hukum yang berkaitan dengan tanah sebagaimana diatur dalam Pasal 2 ayat (2) UUPA. Salah satu bentuk dari kewenangan tersebut adalah melakukan pendaftaran tanah sebagaimana diatur dalam Pasal 19 UUPA yang kemudian dijabarkan dalam peraturan yang lebih operasional yakni Peraturan Pemerintah No. 24 Tahun 1997 tentang Pendaftaran Tanah. Pendaftaran tanah ini memiliki tujuan memberikan kepastian dan perlindungan hukum kepada masyarakat atas tanahnya serta menunjang terciptanya tertib administrasi pertanahan. Kepastian hukum tersebut baik kepastiab mengenai status hukum tanah tersebut yakni jenis hak yang dilekatkan, subjek dan objek hak atas tanah. ${ }^{8}$ Selain itu, terhadap pemilik tanah juga diberikan bukti kepemilikan berupa sertifikat.

Berdasarkan definisi tersebut maka terhadap tanah yang berada di pantai sebagai bagian dari laut dapat diberikan hak atas tanah. Pemberian hak atas tanah bagi masyarakat tradisional di pantai ini dimungkinkan sebagaimana diatur dalam Pasal 5 Peraturan Menteri Agraria Tata Ruang/Kepala Badan Pertanahan Nasional No. 17 Tahun 2016

\footnotetext{
Sukirno, Urgensi Persyaratan Untuk Masyarakat Hukum Adat dalam RUU Pertanahan, Jurnal Masalah-Masalah Hukum, Vol. 42, No. 4, Oktober 2013, hlm. 486. Bandingkan dengan Mochamad Adib Zain, et al., "Pengakuan Atas Kedudukan dan Keberadaan Masyarakat Hukum Adat (MHA) Pasca Dibentuknya Undang-Undang Nomor 6 Tahun 2014 tentang Desa", Penelitian Hukum, Vol. 2, No. 2, Juli 2015, hlm. 70. E. Schagatary, et al., "A Living Based On Breath Hold Living In The Bajau Laut", Journal Human Evolution, Vol. 29, 2016, hlm. 172 Bandingkan dengan Iziq Eafifi Ismail, "Influences of Regional Sama-Bajau Coastal Dwellings: Social Perspectives Throuh Identity Molding”, International Journal of Culture and History, Vol. 1, No. 2, December 2015, hlm. 115.

4 Mattulada, "The Bajau of South Sulawesi and Other Eastern Island of Indonesia", Makalah, disampaikan pada International Confrence On Sama Bajau Community, Makassar, 24-28 Juni, 1995, hlm. 3. Bandingkan dengan Anwar Hafid, 2008, Asal Usul Persebaran Suku Bajo. Unhalu Press, Kendari, hlm. 92.

Sri Susyanti Nur, 2015, "Pola Penguasaan dan Pemanfaatan Perairan Secara Turun Temurun oleh Suku Bajo", Prosiding Seminar Nasional: Kajian Multi Disiplin Ilmu Untuk Mewujudkan Poros Maritim Dalam Pembangunan Ekonomi Berbasis Kesejahteraan Rakyat, Universitas Stikubak, hlm. 8 .

Boedi Harsono, 2008, Hukum Agraria Indonesia: Sejarah Pembentukan Undang-Undang Pokok Agraria, Isi dan Pelaksanaannya, Djambatan, Jakarta, hlm. 6. Definisi yang sama juga dikemukakan dalam Naskah Akademik Rancangan Undang-Undang Pertanahan, hlm. 67.

Bernhard Limbong, 2014, Politik Pertanahan, Pustaka Margaretha, Jakarta, hlm. 25.

Aminuddin Salle, et al., 2010. Hukum Agraria, A.S. Publishing, Makassar, hlm. 109.
} 
tentang Penataan Pertanahan di Wilayah Pesisir.

Hak atas tanah bagi masyarakat tradisional sangat penting karena terkait dengan eksistensi, kebebasan serta harkat dirinya sebagai manusia. Selain itu, kepemilikan hak atas tanah ini juga terkait dengan kesejahteraan masyarakat tradisional. Terbatasnya akses terhadap tanah merupakan salah satu faktor penyebab kemiskinan dalam kaitan terbatasnya aset dan sumber daya produktif yang dapat diakses oleh masyarakat miskin. ${ }^{9}$ Berdasarkan data Badan Pusat Statistik tahun 2016, 63, 47\% penduduk miskin Indonesia berada di pantai dan pedesaan. ${ }^{10}$

Elisabeth Wickeri menyatakan bahwa ketiadaaan tanah merupakan penyebab utama timbulnya kelaparan dan kemiskinan. Dia juga menekankan bahwa ketiadaan tanah akan mengancam pemenuhan hak asasi manusia lainnya. Dalam pandangannnya, tanah merupakan instrumen utama untuk hak-hak ekonomi, sosial dan budaya serta menikmati hak-hak sipil dan politik. Uraian ini menunjukkan bahwa pemberian hak atas tanah bagi masyarakat tradisional terkait dengan pemenuhan kebutuhan dasar ${ }^{11}$ dan kesempatan bagi manusia untuk mengembangkan kehidupannya. ${ }^{12}$ Dalam Minority Right International Report dinyatakan bahwa hak atas tanah memiliki peran yang sangat penting dalam mempercepat pertumbuhan ekonomi, pembangunan sosial dan pengurangan angka kemiskinan. ${ }^{13}$ Adanya hak atas tanah ini akan membuat masyarakat tradisional yang bermukim di pantai bisa mendapatkan perlindungan atas kepemilikannya dan menjadi sarana baginya untuk meningkatkan kesejahteraannya.

Pemberian hak atas tanah merupakan pemenuhan hak konstitusional bagi masyarakat tradisional baik untuk meningkatkan kesejah- teraannya maupun budaya. ${ }^{14}$ Dalam konteks budaya, masyarakat tradisional menempatkan tanah sebagai akar kulturalnya. ${ }^{15}$ Artinya, pemenuhan hak-hak atas tanah bagi masyarakat tradisional juga akan memberikan kesempatan bagi masyarakat tersebut mempertahankan dan mengembangkan budayanya. Berdasarkan uraian di atas maka pembahasan dalam tulisan ini akan difokuskan pada dua masalah yaitu: Pertama, Bagaimanakah perlindungan terhadap hak atas tanah bagi masyarakat tradisional dalam perspektif hak asasi manusia? Kedua, Bagaimanakah prinsip-prinsip perlindungan terhadap hak atas tanah bagi masyarakat tradisional?

\section{B. Metode Penelitian}

Penelitian ini adalah penelitian doktrinal yang mengonsepsikan dan mengembangkan hukum berdasarkan doktrin. ${ }^{16}$ Penelitian ini menggunakan pendekatan undang-undang (statute approach) yang dilakukan melalui telaah terhadap peraturan perundang-undangan, deklarasi dan konvensi internasional yang terkait dengan perlindungan hak atas tanah bagi masyarakat tradisional di pantai. Melalui telaah ini diharapkan dapat diketahui kesesuaian antara berbagai instrumen hukum tersebut dengan perlindungan hak atas tanah bagi masyarakat tradisional di pantai. Selain itu, digunakan pula conceptual approach guna menelaah asas-asas dan konsep-konsep yang berkaitan dengan pemberian hak atas tanah bagi masyarakat tradisional yang mendirikan rumah di pantai.

Penelitian ini menggunakan data sekunder yang terdiri dari: Pertama, bahan hukum primer yakni peraturan perundang-undangan, deklarasi dan konvensi internasional. Kedua, bahan hukum sekunder berupa literatur ilmiah baik buku,

\footnotetext{
Bernhard Limbong, Op.cit, Hlm. 87

Badan Pusat Statistik, 2016, Kajian Sosial dan Ekonomi Desa Maritim, Badan Pusat Statistik, Jakarta. hlm. 3.

Dian Aries Mujiburohman, et al., “Aspek Hak Asasi Manusia Dalam Pengadaan Tanah”, Jurnal Bhumi, No. 40, Oktober 2014 , hlm. 622.

Bahrin, et al., "Luas Lahan dan Pemenuhan Kebutuhan Dasar”, Jurnal Penyuluhan., Vol. 6, No. 1, Maret 2010, hlm. 69.

Minority Rights Group International, Moving Towards A Right To Land: The Committee On Economic, Sosial And Cultural Rights'Treatment Of Land Rights As Human Rights, Minority Rights Group International and University Of East London, London, hlm. 35.

Widhi Handoko, 2014, Kebijakan Hukum Pertanahan : Sebuah Refleksi Keadilan Hukum Progresif, Thafa Media, Yogyakarta, hlm. 3.

Sukirno, 2018, Politik Hukum Pengakuan Hak Ulayat, Prenada Media Group, Jakarta, hlm. 2.

Siti Zulaekhah, "Model Mitigasi Risiko Pada Lembaga Penjaminan Kredit di Indonesia”, Mimbar Hukum, Vol. 30, No. 2, Juni 2018 , hlm. 294.
} 
hasil penelitian dan makalah hak atas tanah bagi masyarakat tradisional di pantai. Bahan hukum sekunder ini bertujuan menjelaskan bahan hukum primer. Ketiga, bahan hukum tersier yakni bahan hukum yang bertujuan memberikan pemahaman dan pengertian atas bahan hukum primer dan bahan hukum sekunder. Analisis data pada penelitian ini dilakukan secara kualitatif yakni keseluruhan data yang dikumpulkan akan dianalisis secara kualitatif. Melalui analisis data secara kualitatif ini diharapkan dapat dipecahkan masalah mengenai perlindungan hak atas tanah bagi masyarakat tradisional di pantai.

\section{Hasil Penelitian dan Pembahasan}

1. Perlindungan Terhadap Hak Atas Tanah Bagi Masyarakat Tradisional dalam Perspektif Hak Asasi Manusia

Pada tanggal 11 Maret 1960, Dewan Pertimbangan Agung memberikan usul dalam perancangan Undang-Undang No. 5 Tahun 1960 tentang Peraturan Dasar Pokok-Pokok Agraria bahwa hukum agraria yang akan dibentuk sudah seharusnyalah sederhana dan menjamin kepastian hukum bagi seluruh masyarakat. ${ }^{17}$ Salah satu bentuk dari kepastian hukum tersebut adalah mengadakan pendaftaran tanah sebagaimana yang terdapat dalam penjelasan umum UUPA. Pendaftaran ini akan menghasilkan bukti kepemilikan tanah berupa sertifikat. Berdasarkan sertifikat tersebut maka masyarakat dapat mempertahankan kepemilikan tanahnya terhadap orang lain. Ini bermakna sertifikat akan memberikan kepastian dan perlindungan hukum kepada masyarakat atas tanahnya. Menurut Mhd Yamin Lubis, kepastian dan perlindungan hukum merupakan fungsi primer dari pendaftaran tanah. ${ }^{18}$ Hal ini selaras dengan pendapat Roscoe Pound bahwa kewajiban negara adalah melindungi kepentingan individual termasuk barang miliknya. ${ }^{19}$

Pendaftaran tanah ini diselenggarakan terhadap semua masyarakat Indonesia termasuk masyarakat tradisional yang mendirikan rumah di pantai. Berdasarkan hukum internasional, masyarakat tradisional dapat dikategorikan sebagai masyarakat minoritas. Definisi minoritas pertama kali diusulkan oleh Francesco Capotorti pada tahun 1977 dalam Special Rapporteur of the United Nations Sub-Commission on Prevention of Discrimination and Protection of Minorities. Dalam usulan tersebut, minoritas didefinisikan sebagai: ${ }^{20}$

A group numerically inferior to the rest of the population of a State, in a non-dominant position, whose members-being nationals of the State-possess ethnic, religious or linguistic characteristics differing from those of the rest of the population and show, if only implicitly, a sense of solidarity, directed towards preserving their culture, traditions, religion or language.

Berdasarkan definisi di atas, terdapat beberapa ciri dari masyarakat tradisional, yaitu: Pertama, memiliki populasi yang lebih sedikit. Kedua, dalam posisi tidak dominan dengan karakteristik etnis, agama ataupun bahasa yang berbeda. Ketiga, solidaritas dalam memelihara tradisi, budaya, agama atau bahasanya. Ketiga kriteria di atas selaras dengan kategori minoritas di Jerman, yakni: ${ }^{21}$ (1) warga negara Jerman; (2) berbeda dengan populasi mayoritas dalam hal bahasa, budaya dan sejarah; (3) memiliki identitas sendiri dan ingin memelihara identitas tersebut; serta (4) hidup secara tradisional. Masyarakat tradisional di Indonesia memenuhi ciri-ciri tersebut karena: Pertama, memiliki jumlah lebih sedikit dibandingkan dengan masyarakat Indonesia pada umumnya yang hidup di daratan. ${ }^{22}$ Kedua, masyarakat tradisional yang

\footnotetext{
Naskah Akademik Undang-Undang No. 5 Tahun 1960 tentang Peraturan Dasar Pokok-Pokok Agraria, hlm. 1.

Mhd. Yamin Lubis, 2010, Hukum Pendaftaran Tanah, Mandar Maju, Bandung, hlm. 9.

Roscoe Pound, 1922, An Introduction to The Philosophy of Law, Oxford University Press, London, hlm. 99.

United Nations Office of The High Commissioner for Human Rights, 2010, Minority Rights: International Standards and Guidance For Implementation, United Nations, New York, hlm. 2.

21 Dieter Kugelmann, "The Protection of Minorities and Indigenous Peoples Respecting Cultural Diversity", Max Planck Yearbook of United Nations Law, Vol. 11, 2007, hlm. 238.

22 Lotte Kemkens, 2009, Living On Baoundaries: The Orang Bajo of Tinakin Laut, Indonesia. Bachelor's Thesis, Utrecht University, Utrecht, hlm. 26.
} 
bermukim di pantai memiliki kepercayaan dan budaya yang berbeda dengan masyarakat pada umumnya. Masyarakat yang hidup di pantai percaya bahwa nenek moyangnya sebagai penguasa lautan dan memiliki budaya yang berbeda dengan budaya perbedaan budaya dengan daratan karena budaya masyarakat tradisional yang bermukim di pantai akan terkait, berakar dan berorientasi pada lautan. Bahkan, masyarakat tradisional yang bermukim di pantai percaya bahwa masyarakat ini ditakdirkan oleh Tuhan untuk menjaga lautan. ${ }^{23}$ Ketiga, masyarakat tradisional yang hidup dan bermukim di lautan memiliki solidaritas yang tinggi untuk memelihara budayanya. Dalam hal ini, bermukim di pantai merupakan upaya mempertahankan identitas diri sebagai orang laut, ketaatan terhadap tradisi yang telah berlangsung lama dan upaya untuk mempertahankan budaya dari satu generasi ke generasi lainnya. ${ }^{24}$

Kekhasan pola hidup, budaya, tradisi, kepercayaan dan jumlah dari masyarakat tradisional yang berbeda dengan masyarakat pada umumnya ini menyebabkan masyarakat tersebut dapat dikategorikan sebagai minoritas. Minoritas ini merupakan masyarakat yang rentan sehingga harus mendapatkan prioritas dalam perlindungan haknya karena memiliki kemampuan yang lebih rendah dari masyarakat pada umumnya untuk mengakses berbagai fasilitas dan pelayanan. ${ }^{25}$ Oleh sebab itu, terhadap masyarakat tradisional perlu diberikan perhatian dan pemberdayaan untuk memastikan pemenuhan hak-haknya dan tidak menjadi korban dari kebijakan pemerintah maupun tindakan masyarakat lainnya. Salah satu hak masyarakat tradisional yang penting adalah hak atas tanah. ${ }^{26}$

Hak atas tanah merupakan salah satu hak asasi manusia sebagaimana yang dikemukakan oleh John Locke melalui formation theory. Locke menyatakan bahwa Tuhan menciptakan alam semesta (tanah) bagi semua manusia. Terhadap bagian-bagian alam semesta (tanah) itu manusia dapat melakukan kerja yang lama kelamaan akan menimbulkan hubungan kepemilikan serta berhak menikmati hasil dari pengelolaan tanah tersebut. ${ }^{27}$ Hubungan kepemilikan yang tercipta antara manusia dan tanah merupakan hak asasi dan kewenangan untuk mempertahankan kepemilikannya merupakan fundamental law of property. ${ }^{28}$

Kesadaran tentang pentingnya hak atas tanah sebagai hak asasi manusia termasuk bagi minoritas telah timbul sejak lama bahkan sejak tahun 1946. Pada tahun tersebut, Komisi Hak Asasi Manusia Perserikatan Bangsa-Bangsa diberikan tugas untuk membuat rekomendasi mengenai penanganan berbagai subjek Hak Asasi Manusia (HAM) termasuk kaum minoritas. Guna melaksanakan hal tersebut maka pada tahun 1947 dibentuk suatu komisi khusus yang terdiri dari para ahli bernama Sub Komisi Pencegahan Diskriminasi dan Perlindungan Kaum Minoritas. Pada tahun 1992 Majelis Umum mengadopsi Declaration on The Rights Of Persons Belonging To National or Ethnic, Religious and Linguistic Minorities. Salah satu hal utama yang menjadi perhatian Perserikatan BangsaBangsa adalah hak atas tanah masyakat minoritas. ${ }^{29}$

Hak atas tanah bagi minoritas termasuk masyarakat tradisional walaupun tidak diatur secara eksplisit dalam Universal Declaration on Human Right (UDHR), The International Covenant on Civil and Political Rights (ICCPR), dan International Covenant on Economic, Social and Cultural Rights (ICESCR) namun terdapat beberapa pasal dalam

\footnotetext{
Mukti Ali, "Mengkomunikasikan Pendidikan dan Melestarikan Kearifan Lokal Orang Bajo, Inferensi", Jurnal Penelitian Sosial Keagamaan. Vol. 11, No. 1, Juni 2017, hlm. 201.

Darmawan Salman, et al., 2011, Jagad Bahari Nusantara, Kementerian Kebudayaan dan Pariwisata, Jakarta , hlm. 8-9.

Preethi Shivayogi, "Vulnerable Populatiom and Methods for Their Safeguard", Perspective in Research, Vol. 4, January-March 2013 , hlm. 54. Carlos Eduardo Artiaga, et al., "Legislative Vulnerability of Minority Groups", Ciencia \& Saude Coletiva, Vol. 22, No. 12, 2017, hlm. 3843. James Tully, 1982, A Discourse On Property: John Locke And His Adversaries, Cambridge University Press, Cambridge, hlm. 59. Ibid., hlm. 61 .

Vladimir Kartashkin, "The Protection of The Rights of Minorities Within The Framework of The United Nations", Revue Quebecoise De Droit International, Vol. 12, 1999, hlm. 37
} 
deklarasi dan konvensi tersebut yang berkaitan dan mendasari perlindungan hak atas tanah bagi minoritas.

Dalam Pasal 17 UDHR diatur bahwa setiap orang berhak untuk memiliki sesuatu baik secara individual maupun berkelompok. Bahkan, dalam Pasal 25 UDHR diatur bahwa:

Everyone has the right to a standard of living adequate for the health and wellbeing of himself and of his family, including food, clothing, housing, medical care and necessary social services, and the right to security in the event of unemployment, sickness, disability, widowhood, old age or other lack of livelihood in circumstances beyond his control.

Hal yang sama juga ditekankan dalam Pasal 17 ICCPR yang menyatakan bahwa setiap orang tidak boleh diperlakukan secara sewenang-wenang atas privasi, keluarga, rumah dan hal yang tekait dengan itu. Sampai saat ini, belum terdapat deklarasi maupun konvensi yang secara khusus mengatur mengenai hak atas tanah bagi minoritas sehingga ketentuan terkait hak atas tanah masih sebatas perluasan penafsiran hak atas perumahan sebagai mana terdapat dalam Komentar Umum 4 ICCPR yang menyatakan bahwa hak terhadap perumahan dalam ICCPR tidak dapat ditafsirkan secara sempit tetapi juga berkaitan dengan perlindungan terhadap hak atas tanah dan akses untuk mendapatkan tanah. ${ }^{30}$

Pengaturan hak atas tanah hanya sebagai perluasan penafsiran terhadap hak atas perumahan merupakan suatu hal yang ironis karena tanah merupakan sumber daya alam yang penting bagi manusia. Keberadaan tanah juga bukan hanya terkait dengan perumahan tapi juga dengan aspekaspek kehidupan lainnya seperti aspek sosial. Bagi manusia, tanah merupakan ruang sosial yang menyatukan manusia. Dari sudut pandang ekonomi, tanah merupakan faktor produksi yang digunakan olehmanusiauntuk kegiatan pertanian, pertambakan, perkebunan dan kegiatan lainnya. Pengaturan tanah hanya sebagai perluasan penafsiran terhadap hak atas perumahan telah mereduksi kompleksitas kegiatan yang terdapat di atas tanah.

Kompleksitas tanah juga terkait dengan keberagaman subyeknya yakni masyarakat perkotaan, masyarakat perdesaan, masyarakat minoritas seperti masyarakat tradisional dan masyarakat hukum adat. Kondisi, kemampuan, kewenangan, pemaknaan, kebutuhan dan organisasi sosial dari masyarakat-masyarakat tersebut berbeda sehingga pengaturan terhadap hak atas tanah bagi kelompok-kelompok tersebut haruslah berbeda. Kondisi yang demikian menunjukkan bahwa kompleksitas tanah termasuk dalam hal keragaman subjek memerlukan pengaturan khusus yang lebih detail dan mampu mengakomodasi keberagaman kegiatan dan subyeknya (kelompok masyarakat). Pengaturan khusus tersebut dapat dibuat dalam bentuk konvensi maupun deklarasi internasional.

Pengaturan tanah hanya sebagai perluasan penafsiran dari hak atas perumahan tidaklah sepenuhnya tepat bagi negara yang menganut asas horizontal scheiding seperti Indonesia. Asas horizontal scheiding bermakna keterpisahan antara kepemilikan tanah dengan bangunan di atasnya. Asas ini didasarkan pada hukum adat sebagai dasar hukum agraria nasional. ${ }^{31}$ Nampaknya, pengaturan hak atas tanah sebagai perluasan penafsiran dari pengaturan hak atas perumahan hanya mengakomodasi negara-negara yang menerapkan asas asesi vertikal yaitu asas yang menyatukan antara kepemilikan tanah dan perumahan di atasnya. ${ }^{32}$ Uraian di atas menunjukkan bahwa pengaturan hak atas tanah sebagai bagian dari perumahan tidak dapat mengakomodasi kepentingan negara

30 The United Nations Interagency Team For Preventive Action, 2012, Toolkit and Guidance For Preventing And Managing Land And Natural Resources Conflict, UN Interagency Team For Preventive Action, New York, hlm. 15.

31 F. Husni Abdullah, “Azas Pemisahan Horizontal (Horizontale Scheiding) Dalam Hukum Tanah di Indonesia dan Permasalahannya”, Hukum dan Pembangunan, Vol. 22, No. 1, 1992. hlm. 79.

32 Musa Anthony Siregar, et al,. Hukum Agraria Atas Keberadaan Bangunan Pada Ruang Atas Tanah, Nuansa Kenotariatan, Vol. 1, No. 1, JuliDesember 2015, hlm. 16 
yang menerapkan asas horizontal scheiding seperti Indonesia.

Berdasarkan penjelasan di atas maka sudah sepatutnya dibuat pengaturan internasional secara tersendiri terhadap hak atas tanah dan bukan hanya perluasan penafsiran dari pengaturan hak atas perumahan. Kesadaran mengenai pentingnya hak atas tanah sebenarnya sudah muncul dalam berbagai konvensi dan deklarasi internasional tapi belum mewujud dalam suatu peraturan khusus sehingga tidak dapat mengatur kompleksitas di bidang pertanahan. Salah satu deklarasi yang menyinggung mengenai hak atas tanah adalah Vancouver Declaration On Human Settlements yang mengatur bahwa kebijakan terkait perumahan dan pertanahan merupakan bagian dari kebijakan sosial. Selaras dengan hal tersebut, dokumen United Nations Center for Human Settlement menyatakan bahwa perlindungan terhadap permukiman dan hak atas tanah merupakan bagian dari upaya menciptakan kesejahteraan. ${ }^{33}$ Perlindungan terhadap hak atas tanah masyarakat tradisional merupakan prasyarat untuk keluar dari kemiskinan. Oleh sebab itu, pemerintah harus menghilangkan berbagai rintangan bagi masyarakat guna mendapatkan hak atas tanah.

Perlindungan hak atas tanah bagi minoritas termasuk masyarakat tradisional sangat penting karena ketiadaan tanah merupakan penyebab utama timbulnya kemiskinan dan kelaparan. ${ }^{34}$ Bahkan, di beberapa negara pemberian hak atas tanah telah menjadi salah satu cara yang efektif untuk menurunkan tingkat kemiskinan. ${ }^{35}$ Dalam Section 84 Report of the Special Rapporteur On Adequate Housing As A Component Of The Right To An Adequate Standard Of Living, And On The Right To Non-Discrimination In This Context On Her Mission To Serbia And Kosovo diatur bahwa terdapat keterkaitan antara kemiskinan dan hak atas tanah. Hal ini mengingat tanah merupakah asset penting masyarakat tradisional sehingga ketiadaan hak atas tanah dapat mengancam akses masyarakat terhadap berbagai hak. Dalam konteks ini, tanah memiliki posisi yang strategis guna menurunkan angka kemiskinan dan menjadi sarana untuk mengakses berbagai hak-hak lainnya. Section 1 Covenant on Economic, Social and Cultural Right General Comment No. 4: The Right to Adequate Housing (Art. 11 (1) of the Covenant) mengatur bahwa hak terhadap perumahan (termasuk tanah) merupakan hal yang penting bagi masyarakat untuk menikmati hak ekonomi, sosial dan budaya. Dalam laporan Minority Rights Group disebutkan bahwa hak atas tanah memiliki peranan penting dalam meningkatkan pertumbuhan ekonomi, pembangunan sosial dan penurunan angka kemiskinan. ${ }^{36}$

Masyarakat tradisional memahami pendirian permukiman di pantai sebagai ekspresi kebudayaan. Bagi masyarakat tradisional terdapat keterkaitan yang erat antara faktor kebudayaan, lokasi permukiman dan bentuk rumah. Dalam hal ini, faktor budaya menjadi salah satu penyebab masyarakat tradisional serta membangun permukiman di pantai. Keterkaitan antara permukiman, tanah dan budaya juga diatur dalam Universal Declaration on Cultural Diversity yang dipelopori oleh United Nations Economic, Social and Cultural Organisation. Dalam deklarasi tersebut diatur bahwa budaya merupakan gambaran spiritual, material, intelektual dan emosional yang kompleks guna mencirikan satu kelompok sosial tertentu yang tidak hanya terbatas pada seni dan sastra namun juga meliputi cara hidup, system nilai, tradisi dan kepercayaan.

Dalam Pasal 7 Draft Convention on the Protection of the Diversity of Cultural Content and Artistic Expression diatur bahwa negara harus

\footnotetext{
33 United Nations Center for Human Settlements (Habitat), 2017, Cities and Homes for All: The Habitat Agenda, United Nations, New York, hlm. 16.

34 Timothy Besley, et al., "Land Reform, Poverty Reduction and Growth: Evidence From India”, DEDPS, Vol. 13, October 1998, hlm. 23.

35 Chandra Bahadur Adhikari, et al., "Economic Relationship Between Access To Land and Rural Pverty in Nepal", Applied Economics Journal, Vol. 21, No. 1, June 2014, hlm. 195.

36 Minority Rights Group International, Op.cit., hlm. 1.
} 
menciptakan lingkungan yang baik bagi minoritas termasuk masyarakat tradisional untuk mendapatkan akses bagi ekspresi budaya nya. Dalam Pasal 8 konvensi tersebut juga diatur bahwa negara harus pula memberikan proteksi bagi masyarakat guna melakukan ekspresi kebudayaan dalam wilayah negaranya. Artinya, negara Indonesia seharusnya memberikan perlindungan terhadap hak atas tanah masyarakat tradisional yang menggunakan wilayah pantai untuk mendirikan pemukiman sebagai ekspresi kebudayaannya.

Berdasarkan uraian tersebut maka pemenuhan hak atas tanah bagi masyarakat tradisional di pantai juga dapat dianggap sebagai pemenuhan hak masyarakat tradisional untuk mempertahankan dan mengembangkan budayanya. Pentingnya perlindungan terhadap hak masyarakat tradisional atas tanah sebagaimana diuraikan di atas menunjukkan bahwa negara bahkan komunitas internasional sudah sepatutnya melakukan langkahlangkah efektif untuk memastikan pemenuhan hak atas tanah masyarakat tradisional.

Guna memenuhi hak masyarakat tradisional tersebut maka pemerintah berkewajiban mengambil langkah-langkah yang efektif untuk memastikan bahwa hak asasi manusia dapat terpenuhi dan di sisi lain penempatan tanah sebagai hak asasi manusia juga membatasi tindakan negara terhadap warganya. Artinya, tindakan negara tidak boleh melanggar hak-hak kepemilikan masyarakat tradisional atas tanah. Secara garis besar kewajiban negara dan komunitas internasional terhadap hak atas tanah bagi masyarakat tradisional dapat dibagi menjadi tiga, yaitu menghormati (respect), melindungi (protect) dan memenuhi (fulfill) hak atas tanah masyarakat tersebut. ${ }^{37}$

Pertama, kewajiban untuk menghormati (respect) bermakna negara memiliki kewajiban untuk menahan diri dari penggunaan tanah yang dimiliki oleh individu maupun kelompok. Kedua, kewajiban untuk melindungi (protect) bermakna negara harus melindungi warga negaranya dari gangguan dari pihak lain. Termasuk dalam kategori ini adalah kewajiban negara untuk membuat peraturan perundang-undangan. Kewajiban pemerintah untuk mengambil tindakan aktif guna menjamin terpenuhinya hak-hak atas tanah bagi kelompok minoritas juga diatur dalam CESCR General Comment No. 4: The Right to Adequate Housing (Art. 11 (1) of the Covenant). Dalam Section 8 huruf a General Comment ini diatur bahwa pemerintah harus mengambil tindakan-tindakan yang berujuan memberikan kepastian hukum atas perumahan (termasuk tanah) terhadap masyarakat yang belum memiliki hak atas tanah. Dalam Pasal 2 ayat (1) General Comment No. 7 ICCPR yang mewajibkan negara memberikan perlindungan hak atas tanah bagi masyarakat tradisional di pantai. Perlindungan negara tersebut dapat dibagi dua, yaitu: (a) memberikan perlindungan maksimal bagi pemilik tanah; dan (b) mencegah terjadinya konflik. Ketiga, kewajiban untuk memenuhi (fulfill) berarti negara memiliki kewajiban untuk mengambil langkah-langkah guna menjamin bahwa hak asasi manusia bisa dinikmati oleh setiap masyarakat. ${ }^{38}$

\section{Prinsip-Prinsip Perlindungan Terhadap Hak Atas Tanah Bagi Masyarakat Tradi- sional}

Berdasarkan uraian pada bagian terdahulu, hak atas tanah sebagai hak asasi manusia haruslah dapat diakses oleh semua pihak dan mencerminkan nilai-nilai keadilan. Guna mewujudkan hal tersebut maka Minority Rights Group International menyatakan bahwa setidaknya terdapat beberapa prinsip dari perlindungan hak atas tanah utamanya bagi masyarakat minoritas termasuk masyarakat tradisional. Adapun prinsip-prinsip tersebut adalah: ${ }^{39}$

\footnotetext{
37 Inter-Parliamentary Union, 2016, Human Rights: Handbook For Parliamentarian No. 26, Inter-Parliamentary Union - UNHR, Geneva, hlm. 19.

38 Ibid, hlm. 31-33

39 Minority Rights Group International, Op.cit., hlm. 8.
} 
a. Nondiskriminasi

Perolehan hak atas tanah bagi masyarakat tradisional di pantai haruslah didasarkan pada prinsip nondiskriminasi. Prinsip ini memberikan kesempatan bagi semua masyarakat untuk mendapatkan akses terhadap sumber daya alam termasuk tanah. ${ }^{40}$ Menurut United Nations Human Rights Office of The High Commissioner, terdapat dua bentuk diskriminasi, yaitu diskriminasi secara langsung dan diskriminasi secara tidak langsung. Diskriminasi secara tidak langsung bersifat lebih halus sehingga lebih susah untuk disadari bahkan dihilangkan. Diskriminasi secara tidak langsung terjadi apabila peraturan ataupun syarat yang ditetapkan tampak netral tetapi memiliki dampak yang tidak baik terhadap kelompok tertentu. Bahkan, peraturan tersebut bisa saja menghalangi masyarakat untuk mendapatkan hak atas tanah.

Guna mencegahterjadinyadiskriminasi secara tidak langsung maka dalam pembuatan peraturan perundang-undangan perlu diperhatikan perbedaan kemampuan dalam masyarakat untuk memperoleh hak tersebut baik dalam hal persyaratan maupun mekanismenya. Dalam hal ini, haruslah diwaspadai adanya kebijakan atau peraturan perundang-undangan yang secara teks netral tetapi sesungguhnya berpotensi menimbulkan diskriminasi disebabkan oleh perbedaan kemampuan dalam masyarakat. ${ }^{41}$

Prinsip nondiskriminasi pada hakikatnya bertujuan menjamin masyarakat bisa memiliki akses yang sama guna mendapatkan hak atas tanah sebagaimana diatur dalam Pasal 26 ICCPR bahwa:

Allpersons are equal before the law and are entitled without any discrimination to the equal protection of the law. In this respect, the law shall prohibit any discrimination and guarantee to all persons equal and effective protection against discrimination on any ground such as race, colour, sex, language, religion, political or other opinion, national or social origin, property, birth or other status.

Substansi Pasal 26 ICCPR ini kemudian ditegaskan dalam Pasal 27 ICCPR yang menyatakan bahwa:

In those States in which ethnic, religious or linguistic minorities exist, persons belonging to such minorities shall not be denied the right, in community with the other members of their group, to enjoy their own culture, to profess and practise their own religion, or to use their own language.

Substansi Pasal 26 dan Pasal 27 ICCPR di atas menekankan bahwa semua orang harus diperlakukan secara sama, tanpa diskriminasi serta mendapatkan perlindungan efektif tanpa membedakan ras, warna kulit, jenis kelamin, bahasa dan status lainnya. Perkataan status lainnya tersebut mencakup minoritas sehingga masyarakat tradisional tidak boleh didiskriminasi untuk mendapatkan hak atas tanah. Ketiadaan diskriminasi tersebut termasuk pula dalam hal syarat-syarat yang diterapkan untuk mendapatkan hak atas tanah haruslah sama bahkan lebih mudah mengingat kondisi sosial, ekonomi, dan budaya dari masyarakat tradisional.

Adanya syarat yang lebih mudah ini juga sesungguhnya tidak bertentangan dengan prinsip nondiskriminasi karena prinsip ini memberi ruang bagi adanya perlakuan khusus apabila terdapat perbedaan kemampuan dalam mendapatkan hak atas tanah agar minoritas termasuk masyarakat

United Nations Office of The High Commissioner for Human Rights, Op.cit., hlm. 5.

Ibid, hlm. 19. 
tradisional bisa mendapatkan hak atas tanah sebagaimana ditegaskan oleh Komisi Hak Asasi Manusia ketika menguraikan makna dari Pasal 27 ICCPR. ${ }^{42}$ Uraian di atas juga selaras dengan prinsip-prinsip dalam Deklarasi Perlindungan Minoritas yang diantaranya adalah kewajiban negara untuk melindungi dan menghormati hak minoritas. Perlindungan terhadap minoritas adalah perlindungan terhadap keberagaman identitas sehingga nantinya tidak terjadi diskriminasi terhadap masyarakat yang bersangkutan.

Laporan dari Minority Group International juga menunjukkan bahwa walaupun terdapat prinsip nondikriminasi tetapi prinsip tersebut juga memperbolehkan adanya perlakuan khusus bagi masyarakat minoritas atau yang dalam pembahasan ini adalah masyarakat tradisional. Dimungkinkan adanya perlakuan khusus ini terdapat pula dalam Section 11 CESCR General Comment No. 4: The Right to Adequate Housing (Art. 11 (1) of the Covenant) yang mengatur bahwa negara harus memberikan prioritas bagi kelompok-kelompok sosial yang hidup dalam kondisi tidak beruntung. Artinya, kebijakan dan peraturan perundangundangan seharusnya mendukung penciptaan akses yang lebih baik bagi masyarakat untuk mendapatkan hak atas tanah.

Penciptaan akses yang lebih mudah bagi masyarakat yang kurang beruntung ini sesuai dengan teori keadilan yang dikemukakan oleh John Rawls. Dalam teori tersebut diatur bahwa terdapat dua prinsip keadilan, yaitu: pertama, prinsip bahwa semua orang memiliki hak dan kewajiban yang setara; kedua adalah ketidaksetaraan sosial dan ekonomi dalam masyarakat seperti ketidaksetaraan kemampuan ekonomi hanya adil jika memberikan kesempatan yang lebih luas (prioritas) bagi orang yang kurang beruntung. Prinsip ini disebut sebagai different principle. ${ }^{43}$ Penerapan different principle ini diharapkan dapat menciptakan keseimbangan dalam memperoleh hak atas tanah antara masyarakat yang kurang beruntung dan masyarakat yang beruntung.

Pakar lainnya yang juga mengemukakan pendapatnya tentang keadilan adalah Mubyarto yang menyatakan bahwa guna menciptakan keadilan (termasuk akses dalam mendapatkan hak atas tanah) maka terdapat tiga prinsip yang wajib untuk ditegakkan, yaitu:44 Pertama, prinsip hak dan kewajiban. Prinsip ini bermakna keadilan dapat terwujud apabila hak yang dimiliki oleh masyarakat dilindungi oleh hukum dan adanya kewajiban dari pihak lain untuk menghormati hak dari orang tersebut. Kedua, adanya prinsip reward and punishment. Prinsip reward and punishment menghendaki agar para pihak yang melanggar hak-hak orang lain dihukum. Ketiga, prinsip pemenuhan kebutuhan. Hal ini bermakna bahwa guna mewujudkan keadilan, negara wajib memberikan kepada setiap anggotanya apa yang mereka butuhkan.

Section 8 (a) CESCR General Comment No. 4: The Right to Adequate Housing (Article 11 (1) of the Covenant) mengatur bahwa aspek aksesibilitas merupakan hal yang penting terkait dengan hak atas tanah. Berdasarkan hal tersebut maka pemerintah harus memberikan akses yang lebih mudah bagi kelompok yang kurang beruntung. Oleh karena itu, sudah sepatutnya memberikan prioritas dan kemudahan dalam perolehan

\footnotetext{
42 Patrick Macklem, "Minority Rights in International Law”, International Journal Of Constitutional Law, Vol. 6, Issue 3-4, July 2008, hlm. 539. Bandingkan dengan Elena Andreevska, "Protection of Minorities and The Prohibition of Discrimination: The Ohird Framework Agreement", American International Journal of Contemporary Research, Vol. 3, No. 5, May 2013, hlm. 63.

43 John Rawls, 1971, A Theory of Justice, Harvard University Press, Harvard, hlm. 15.

44 Mubyarto, 1987, Ekonomi Pancasila: Gagasan dan Kemungkinan, LP3ES, Jakarta, hlm. 6.
} 
hak atas tanah bagi minoritas termasuk masyarakat tradisional sehingga semua masyarakat dapat memperoleh hak atas tanah dan hidup dalam kesejahteraan.

\section{Dalam Section 3 The Rio Declaration}

\section{on Environment and Development}

Tahun 1992 juga diatur bahwa kebijakan pembangunan, pengelolaan sumber daya alam dan pengurangan kemiskinan haruslah terintegrasi dengan tujuan memperbaiki akses kepada yang miskin untuk memperoleh berbagai hak termasuk hak atas tanah melalui pemberdayaan masyarakat yang kurang beruntung. Selain itu, pemerintah juga diminta mengembangkan kebijakan yang memperhatikan masyarakat tradisional. Substansi deklarasi ini memiliki keterkaitan yang sangat erat dengan masyarakat tradisional karena masyarakat tradisional merupakan masyarakat yang miskin dan hidup secara tradisional yang perlu mendapat perhatian. Hal ini juga sesuai dengan General Principles Of Human Settlement dalam The Vancouver Declaration On Human Settlements yang menyatakan bahwa pengaturan mengenai perumahan termasuk hak atas tanah harus memberikan prioritas bagi masyarakat yang tidak beruntung.

Ini juga sesuai dengan sepuluh prinsip dalam perlindungan permukiman dan hak atas tanah bagi masyarakat yang diantaranya menyatakan bahwa di negaranegara berkembang haruslah diberikan perhatian terhadap pemenuhan hak atas tanah bagi orang yang kurang beruntung dan juga masyarakat rentan. Jaminan perlindungan bagi masyarakat minoritas terhadap hak atas tanah bertujuan mencegah terjadinya diskriminasi. ${ }^{45}$

\section{b. Self-determination}

Self-determination dapatlah didefinisi- kan sebagai hak untuk menentukan nasib sendiri. Prinsip ini awalnya berlaku dalam bidang politik namun saat ini telah meluas hingga ke aspek ekonomi, sosial dan budaya ${ }^{46}$ Hal ini tampak dalam Pasal 1 ICESCR yang mengatur bahwa: "All peoples have the right of self-determination. By virtue of that right they freely determine their political status and freely pursue their economic, social and cultural development."Self-determination dalam konteks perlindungan minoritas adalah hak masyarakat minoritas untuk menggunakan suatu wilayah berdasarkan keinginan dan tujuannya. Ini dianggap penting karena terkait dengan hak masyarakat untuk menikmati pembangunan ekonomi, sosial dan budaya.

c. Implementasi yang Bersifat Progresif.

Prinsip ini terkait dengan kewajiban negara untuk bertindak secara sungguhsungguh dan efektif guna memenuhi hakhak minoritas termasuk hak atas tanah. Perlindungan terhadap minoritas tersebut bukan hanya dalam peraturan perundangundangan tetapi juga dalam penerapannya. Dalam konvensi mengenai masyarakat minoritas, cakupan kewajiban pemerintah itu ruang lingkupnya menjadi lebih luas karena meliputi tindakan legislatif, eksekutif, administratif, anggaran dan instrumen pengaturan lainnya bahkan apabila dibutuhkan pemerintah juga dapat melibatkan organisasi nonpemerintah.

d. Partisipasi yang efektif dan persetujuan masyarakat tradisional

Partisipasi masyarakat yang efektif merupakan suatu hal yang sangat penting dalam proses pembuatan, pelaksanaan dan pengawasan kebijakan terkait hak atas tanah bagi masyarakat tradisional yang bermukim di pantai. Hal ini juga bertujuan 
menciptakan transparansi dalam pembuatan kebijakan terkait hak atas tanah di pantai dan mendapatkan dukungan dari masyarakat. Saat ini, dalam hukum internasional juga telah dikembangkan prinsip Free, Prior and Informed Consent (FPIC). Prinsip ini bermakna bahwa persetujuan masyarakat dalam pembuatan kebijakan tentang hak atas tanah di pantai bagi masyarakat tradisional haruslah diberikan secara bebas tanpa paksaan dari pihak manapun serta aspirasi masyarakat menjadi pertimbangan dan turut menentukan dalam pengambilan keputusan. ${ }^{47}$

Berdasarkan prinsip FPIC di atas maka kehendak untuk menjadikan masyarakat sebagai bagian dari pengambil keputusan adalah bentuk partisipasi asli dan bukan partisipasi semu. Partisipasi asli adalah keterlibatan masyarakat secara demokratis ${ }^{48}$ dalam menentukan tujuan, merancang perencanaan, pelaksanaan dan pengawasan. ${ }^{49}$ Partisipasi asli ini memberikan kesempatan bagi masyarakat untuk turut serta dalam membuat kebijakan dan pengambilan keputusan. Kondisi ini berbeda dengan partisipasi semu yang tidak memberikan ruang bagi masyarakat untuk turut serta menetukan kebijakan yang akan diambil. ${ }^{50}$

Apabila merujuk pada tangga partisipasi Arnstein maka partisipasi masyarakat yang diharapkan dari prinsip FPIC berada pada tingkatan tertinggi yaitu citizen power. Pada tingkatan ini terdapat tiga tahap, yaitu partnership, delegated power dan citizen control. ${ }^{51}$ Pada tahap partnership, masyarakat dapat berunding dengan pihak pemerintah dan terjadi kesepakatan untuk membagi tanggung jawab dalam hal perencanaan dan pengambilan keputusan. Pada tahap berikutnya, delegated power berarti masyarakat bernegosiasi dengan pemerintah dan memiliki pengaruh dalam pengambilan keputusan. Pada tahap tertinggi adalah citizen control, pada tahap ini masyarakat mengendalikan pengambilan keputusan. Melalui keterlibatan masyarakat dalam pengambilan keputusan maka harapan dan karakter sosial masyarakat tradisional dapat diakomodasi dalam pengambilan keputusan. Selain itu, masyarakat juga dapat memastikan bahwa eksistensi dan keberlangsungan budayanya yang memiliki keterkaitan erat dengan kepemilikan tanah dapat dijaga dan dikembangkan. Berdasarkan penerapan keempat prinsip tersebut diharapkan hak masyarakat tradisional atas tanah dapat terpenuhi.

\section{Kesimpulan}

Berdasarkan hal-hal yang diuraikan diatas terdapat beberapa kesimpulan, yaitu: Pertama, saat ini tidak terdapat pengaturan spesifik mengenai hak atas tanah bagi masyarakat tradisional sebagai minoritas dalam deklarasi maupun konvensi internasional namun terdapat beberapa pasal dalam UDHR, ICCPR, dan ICESCR yang berkaitan dengan hal tersebut. Hak atas tanah dalam General Comment No. 4 ICESCR hanya dikategorikan sebagai bagian dari hak atas perumahan. Hal ini tidaklah tepat, karena: (1) pemanfaatan tanah bersifat kompleks baik dari sisi kegiatan maupun subyeknya; (2) tidak selaras dengan asas horizontal scheiding. Hak atas

Thuy Thu Pham, et al., "Adapting Free, Prior and Informed Consent (FPIC) to Local Contexts in REDD+: Lesson From Three Experiments in Vietnam", Forest, Vol. 6, Issue 7, 2015, hlm. 2409.

48 Yuliandri, 2010, Asas-Asas Pembentukan Peraturan Perundang-Undangan Yang Baik : Gagasan Pembentukan Undang-Undang Berkelanjutan, Rajawali Pers, Jakarta, hlm. 118.

49 Stephen Meno, 2016, Thinking in Circles: A System Theory Approach to Public Participation in Planning, Massachussets Amherst, Massachussets, hlm. 13

50 Tosun Cevat, "Towards A Typology of Community Participation In The Tourism Development Process", Anatolia, Vol. 10, No. 2, 1999, hlm. 115 .

51 Ibid. 
tanah bagi masyarakat tradisional ini merupakan bentuk perlindungan budaya. Kedua, berkaitan dengan hak atas tanah masyarakat tradisional, negara dan komunitas internasional berkewajiban menghormati, melindungi dan memenuhi hak tersebut. Dalam hal ini, negara wajib melaksanakan beberapa prinsip, yaitu: (1) prinsip nondiskriminasi; (2) prinsip Self-determination; (3) implementasi yang progresif; (4) partisipasi yang efektif dan persetujuan masyarakat tradisional.

\section{DAFTAR PUSTAKA}

\section{A. Buku}

Hafid, Anwar, 2008, Asal Usul Persebaran Suku Bajo, Unhalu Press, Kendari.

Handoko, Widhi, 2014, Kebijakan Hukum Pertanahan: Sebuah Refleksi Keadilan Hukum Progresif, Thafa Media, Yogyakarta. Harsono, Boedi, 2008, Hukum Agraria Indonesia: Sejarah Pembentukan Undang-Undang Pokok Agraria, Isi dan Pelaksanaannya, Djambatan, Jakarta.

Inter-Parliamentary Union, 2016, Human Rights: Handbook For Parliamentarian No. 26, Inter-Parliamentary Union - UNHR, Geneva.

Limbong, Bernhard, 2014, Politik Pertanahan, Pustaka Margaretha, Jakarta.

Lubis, Mhd. Yamin, 2010, Hukum Pendaftaran Tanah, Mandar Maju, Bandung.

Meno, Stephen, 2016, Thinking in Circles: A System Theory Approach to Public Participation in Planning, Massachussets Amherst, Massachussets.

Minority Rights Group International, Moving Towards A Right To Land: The Committee On Economic, Sosial And Cultural Rights' Treatment Of Land Rights As Human Rights, Minority Rights Group International and University Of East London, London.

Mubyarto, 1987, Ekonomi Pancasila: Gagasan dan Kemungkinan, LP3ES, Jakarta.

Pound, Roscoe, 1922, An Introduction to The Philosophy of Law, Oxford University Press, London.

Rawls, John, 1971, A Theory of Justice, Harvard University Press, Harvard.

Salle, Aminuddin, et al., 2010. Hukum Agraria,
A.S. Publishing, Makassar.

Salman, Darmawan et al, 2011, Jagad Bahari Nusantara, Kementerian Kebudayaan dan Pariwisata, Jakarta.

Sukirno, 2018, Politik Hukum Pengakuan Hak Ulayat, Prenada Media Group, Jakarta.

The United Nations Interagency Team For Preventive Action, 2012, Toolkit and Guidance For Preventing And Managing Land And Natural Resources Conflict, UN Interagency Team For Preventive Action, New York.

Tully, James, 1982, A Discourse On Property: John Locke And His Adversaries, University Press, Cambridge.

United Nations Center for Human Settlements (Habitat), 2017, Cities and Homes for All: The Habitat Agenda, United Nations, New York.

United Nations Office of The High Commissioner for Human Rights, 2010, Minority Rights: International Standards and Guidance for Implementation, United Nations, New York. Yuliandri, 2010, Asas-Asas Pembentukan Peraturan Perundang-Undangan Yang Baik: Gagasan Pembentukan Undang-Undang Berkelanjutan, Rajawali Pers, Jakarta.

\section{B. Artikel Jurnal}

Abdullah, F. Husni, "Azas Pemisahan Horizontal (Horizontale Scheiding) Dalam Hukum Tanah di Indonesia dan Permasalahannya", Hukum dan Pembangunan, Vol. 22, No. 1, 1992.

Adhikari, Chandra Bahadur et al., "Economic Relationship Between Access To Land and 
Rural Poverty in Nepal", Applied Economics Journal, Vol. 21 No. 1, June 2014.

Ali, Mukti, "Mengkomunikasikan Pendidikan dan Melestarikan Kearifan Lokal Orang Bajo, Inferensi”, Jurnal Penelitian Sosial Keagamaan. Vol. 11, No. 1, Juni 2017.

Andreevska, Elena, "Protection of Minorities and The Prohibition of Discrimination: The Ohird Framework Agreement", American International Journal of Contemporary Research, Vol. 3, No. 5, May 2013.

Artiaga, Carlos Eduardo, et al., "Legislative Vulnerability of Minority Groups", Ciencia \& Saude Coletiva, Vol. 22, No. 12, 2017.

Bahrin, et al., "Luas Lahan dan Pemenuhan Kebutuhan Dasar", Jurnal Penyuluhan, Vol. 6, No. 1, Maret 2010.

Besley, Timothy, et al., "Land Reform, Poverty Reduction and Growth: Evidence From India", DEDPS, Vol. 13, October 1998.

Castellino, Joshua et al., "Self-determination, Indigenous People and Minorities", Macquarie Law Journal, Vol 3, 2003.

Ismail, Iziq Eafifi, "Influences of Regional SamaBajau Coastal Dwellings: Social Perspectives Throuh Identity Molding", International Journal of Culture and History, Vol. 1, No. 2, December 2015.

Kartashkin, Vladimir, "The Protection of The Rights of Minorities Within The Framework of The United Nations", Revue Quebecoise De Droit International, Vol. 12, 1999.

Kugelmann, Dieter, "The Protection of Minorities and Indigenous Peoples Respecting Cultural Diversity", Max Planck Yearbook of United Nations Law, Vol. 11, 2007

Macklem, Patrick, "Minority Rights in International Law", InternationalJournalOfConstitutional Law, Volume 6, Issue 3-4, July 2008.

Menggala, Sidi Rana, "Kemiskinan Pada Masyarakat Nelayan di Cilincing", Indonesian Journal of Public Administration, Vol. 2, No. 1, JanuariJuni 2016.
Mujiburohman, Dian Aries, et al., "Aspek Hak Asasi Manusia Dalam Pengadaan Tanah", Jurnal Bhumi, No. 40, Oktober 2014.

Siregar, Musa Anthony, et al., "Hukum Agraria Atas Keberadaan Bangunan Pada Ruang Atas Tanah", Nuansa Kenotariatan, Vol. 1, No. 1, Juli-Desember 2015.

Nawaz, M.K, "The Meaning and Range of The Principle of Self-determination", Duke Law Journal, Vol. 82, 1965.

Pham, Thuy Thu, et al., "Adapting Free, Prior and Informed Consent (FPIC) to Local Contexts in REDD+: Lesson From Three Experiments in Vietnam", Forest, Vol. 6, Issue 7, 2015.

Schagatary, E, "A Living Based On Breath Hold Living In The Bajau Laut", Journal Human Evolution, Vol. 29, 2014.

Shivayogi, Preethi, "Vulnerable Populatiom and Methods for Their Safeguard", Perspective in Research, Vol. 4, January-March 2013.

Sukirno, "Urgensi Persyaratan Untuk Masyarakat Hukum Adat dalam RUU Pertanahan", Masalah-Masalah Hukum, Vol. 42, No. 4, Oktober 2013.

Tosun, Cevat, "Towards A Typology of Community Participation In The Tourism Development Process”, Anatolia, Vol. 10, No. 2, 1999.

Zain, Mochamad Adib, et al., "Pengakuan Atas Kedudukan dan Keberadaan Masyarakat Hukum Adat (MHA) Pasca Dibentuknya Undang-Undang Nomor 6 Tahun 2014 tentang Desa", Penelitian Hukum, Vol. 2, No. 2, Juli 2015.

Zulaekhah, Siti, "Model Mitigasi Risiko Pada Lembaga Penjaminan Kredit di Indonesia", Mimbar Hukum, Vol. 30, No. 2 Juni 2018.

\section{Tugas Akhir}

Kemkens, Lotte, 2009, Living On Boundaries : The Orang Bajo of Tinakin Laut, Indonesia, Bachelor's Thesis, Utrecht University, Utrecht. 
D. Makalah

Mattulada, "The Bajau of South Sulawesi and Other Eastern Island of Indonesia”, Makalah, disampaikan pada International Confrence On Sama Bajau Community, Makassar, 2428 Juni, 1995.

\section{E. Peraturan Perundang-undangan}

Undang-Undang Dasar Negara Republik Indonesia Tahun 1945.

Undang-Undang Nomor 39 Tahun 1999 tentang Hak Asasi Manusia (Lembaran Negara Nomor 165 Tahun 1999, Tambahan Lembaran Negara Republik Indonesia Nomor 3886).

Undang-Undang Nomor 1 Tahun 2014 tentang Perubahan Undang-Undang No. 27 Tahun 2007 tentang Pengelolaan Wilayah Pesisir dan Pulau-Pulau Kecil (Lembaran Negara Republik Indonesia Tahun 2014 Nomor 2, Tambahan Lembaran Negara Republik Indonesia Nomor 5490).

\section{F. Dokumen Lain}

Covenant on Civil and Political Rights.

Covenant on Economic, Social and Cultural Right.

Covenant on Economic, Social and Cultural Right General Comment No. 4.

Declaration on The Rights Of Persons Belonging To National or Ethnic, Religious and Linguistic Minorities.

The Rio Declaration on Environment and Development.

The Vancouver Declaration On Human Settlements. Universal Declaration on Cultural Diversity. Universal Declaration on Human Rights. 